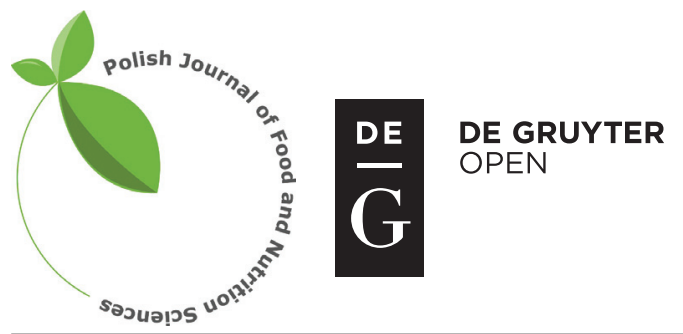

Pol. J. Food Nutr. Sci., 2017, Vol. 67, No. 2, pp. 129-136 DOI: $10.1515 /$ pjfns-2016-0023 http://journal.pan.olsztyn.pl

Original research article

Section: Food Technology

\title{
Qualitative Performance and Consumer Acceptability of Starch Films for the Blueberry Modified Atmosphere Packaging Storage
}

\author{
Nicole R. Giuggioli*, Vincenzo Girgenti, Cristiana Peano
}

\author{
DISAFA, Università degli Studi di Torino, Largo Braccini 2, Grugliasco (TO) 10095, Italy
}

Key words: Vaccinium corymbosum, biodegradable and compostable films, supply chain, MAP, sensory evaluation

The sustainability of packaging is an important part of food system innovation and it can influence the purchase decision for the fresh produce. In this work, we evaluated the qualitative performance and the consumer acceptability of three starch films for the blueberry modified atmosphere packaging (MAP) storage under fluctuating temperatures. Fruits cv. Duke were monitored for up to 18 days $\left(15\right.$ days at $1 \pm 1^{\circ} \mathrm{C}$ and 3 days at $20 \pm 1^{\circ} \mathrm{C}$ ). The respiration rate of the blueberries and the permeability of the films affect the initial atmospheric composition $\left(0.2 \mathrm{kPa} \mathrm{CO}_{2}\right.$ and $\left.21.2 \mathrm{kPa} \mathrm{O}_{2}\right)$ inside each package influencing the headspace gas composition and the quality parameters of the fruits. The $\mathrm{F} 3 \mathrm{film}$ has better controlled $\mathrm{O}_{2}$ values inside the packages up until the end of storage $(5.7 \mathrm{kPa})$ and it maintained the highest anthocyanin content $\left(156.21 \mathrm{mg} \mathrm{C} \mathrm{G}_{3} / 100 \mathrm{~g} \mathrm{FW}\right)$ and antioxidant capacity $\left(22.18 \mathrm{Fe}^{2+} / \mathrm{kg}\right)$ of fruits at $20 \pm 1^{\circ} \mathrm{C}$.

\section{INTRODUCTION}

The blueberry is one of the most important soft fruits; it has become an increasingly popular crop that is available all year round in Italy whose total production in 2012 was approximately 1200 tonnes according to Faostat data [Faostat, 2012]. The nutraceutical properties of blueberries and their integrated and organic cropping systems influence their perceived status as wholesome and healthy fruits [Girgenti et al., 2013], and therefore the packaging should also contribute to this image. Half the blueberry production went towards exports, and the fresh packaged berries are the most important way to market these fruits. The fruit appearance, the flavor and the high nutritive value are keys to successfully gaining the consumer's acceptability [Díaz et al., 2011; Duarte et al., 2009], and their maintenance during packing, storage and transport ensure that the berries display their maximum value and garner the highest market price at the time of sale [Bower, 2007]. Post-harvest loss in terms of value and consumer quality attributes can occur at any stage between harvest and consumption. The managing of the temperature with other technologies can manipulate the fresh produce respiration rate, together with the gas concentration, and/or film/ package permeability (controlled atmosphere storage, modified atmosphere packaging, equilibrium modified atmosphere packaging, and vacuum packaging) having the greatest effects on the shelf life and marketability of the fruits [Paniagua et al., 2014]. The optimum conditions recommended for blueberry

\footnotetext{
* Corresponding Author: Tel.: +39011 670 8646; Fax:+39 0116708658

E-mail: nicole.giuggioli@unito.it (N. Giuggioli)
}

storage are $0^{\circ} \mathrm{C}$ and $90 \%$ RH [Perkins-Veazie et al., 2004] and fruits, when held at or below $5^{\circ} \mathrm{C}$, benefit from 10 to $15 \% \mathrm{CO}_{2}+1$ to $10 \% \mathrm{O}_{2}$ [Prange et al., 1995]. The recommended $\mathrm{CO}_{2}$ values are $17-18 \%$ and an $\mathrm{O}_{2}$ value $\leq 9 \%$ extend Coville blueberry shelf life. The optimum gas compositions were reported by Yam \& Lee [1995] as 11-20\% and 0-10\%, respectively, for the $\mathrm{CO}_{2}$ and the $\mathrm{O}_{2}$. The blueberries cv. Duke changed in terms of flavor, firmness, and acid content if maintained at a $\mathrm{CO}_{2}$ level greater than $12 \%$ [Alsmairat et al., 2011]. Packaging that adds extra benefits to a product can be an important preservation technique for retaining the post-harvest quality and extending the shelf life of blueberries [Junqueira-Gonçalves et al., 2013]. The types of packaging used for fresh horticultural produce handling include different materials such as wood crates, corrugated shipping boxes, polymeric film pouches, bags, baskets, crates, trays, paper sheets, and pouches to respond to specific needs [Bower, 2007]. The new packaging attributes are associated with a lower environmental impact and they must include a selection of more renewable materials enhancing the efficiency and energy consumption associated with sourcing, producing and converting packaging materials [Wikström et al., 2014]. They should also be a better alternative than a packaging system with a higher environmental impact and reduce food waste [Wikström et al., 2014]. The effect of bio-based packaging on the shelf life of blueberries and other types of fresh produce is reported in previous studies. Joo et al. [2011] comparing the shelf life of blackberries using closed packages made from oriented polylactic acid (OPLA) and petroleum based containers, showed how both packages were agree to the standards grade for the commercialization. PLA containers were used to in- 
crease the shelf life of blueberries at different storage temperatures [Almenar et al., 2008] and the consumers generally were able to distinguish and positively evaluate the PLA packaging [Almenar et al., 2010]. Cherry tomatoes and peaches were selected to develop and to optimize equilibrated modified atmosphere packaging (EMAP) using PLA films [Briassoulis et al., 2013]. Among biopolymers, starch is one of the most studied for food packaging applications because of its availability, biodegradability and low cost, but its mechanical performance and hydrophilic characteristics represent a critical point for the use of this natural polymer. Researches on starch-based films have shown that such films could be suitable alternatives to conventional plastics for different food products [Peelman et al., 2013; Peano et al., 2013; Briano et al., 2015]. The berries in growing conditions of Europe are manually harvested and they are directly picked into baskets with which they are transported from fields to a packing house; so the use of flexible films to wrap and to pack blueberries with or without modified atmosphere might be more advantageous than the use of other packaging such as clamshell in terms of product handling. Applications of biodegradable materials from starch corn to store highly perishable fruits such as blueberry under passive MAP are limited. This study aims to investigate the performance of films from starch corn applied for storage of blueberry fruits (cv. Duke) under fluctuating temperature such as in the supply chain and to manage passive modified atmosphere packaging (MAP), comparing the new films with that currently used at retail points. The most important qualitative traits and the nutraceutical components of stored berries will be considered with the most relevant criteria to consumers and preference to evaluate the acceptability of the new tested films.

\section{MATERIALS AND METHODS}

\section{Sample preparation and storage conditions}

Blueberry (Vaccinium corymbosum L.) samples cv. Duke were obtained from a commercial orchard of the Agrifrutta Soc. Coop. SRL (Piedmont, Italy). The fruits were hand-picked in PLA baskets at the end of July at commercial maturity. Samples were uniform in size and lacked any visual injuries or shrivelling. After the picking, the fruits were transported in less than an hour to the packing house (Peveragno, Cuneo, Italy) where the different packaging procedures were carried out (approximately $3 \mathrm{~h}$ after harvest). The films used for the packaging were: one commercial polypropylene macroperforated film (6-mm holes) (F1) that is actually used in Italian retail distribution (Trepack, Italy, $25 \mu \mathrm{m}$ ) and three non-commercial biodegradable and compostable films that were non-perforated (prototypes, Novamont, Italy) (F2 of $25 \mu \mathrm{m}$, $\mathrm{F} 3$ of $15 \mu \mathrm{m}$ and $\mathrm{F} 4$ of $25 \mu \mathrm{m}$ ).

The starch film prototypes characterization has been largely studied in a previous work [Briano et al., 2015]. In Table 1 the oxygen transmission rate $\left(\mathrm{O}_{2} \mathrm{TR}\right)$ and the carbon dioxide transmission rate $\left(\mathrm{CO}_{2} \mathrm{TR}\right)$ values are reported at $20 \pm 1^{\circ} \mathrm{C}$ and $1 \pm 1^{\circ} \mathrm{C}$ (temperatures of the storage trial). Each tray containing $0.125 \mathrm{~kg}$ of fruit (size $9.5 \times 14 \times 5 \mathrm{~cm}$; consumer unit) was hermetically sealed with a Taurus 700 (Delphin, Italy) flow pack machine under ordinary atmo- spheric conditions $\left(0.2 \mathrm{kPa} \mathrm{CO}\right.$ and $\left.20.8 \mathrm{kPa} \mathrm{O}_{2}\right)$. The blueberries were stored at $1 \pm 1^{\circ} \mathrm{C}$ at $90-95 \% \mathrm{RH}$ in a cold room for 15 days. After the cool storage, the fruits were removed and held in the laboratory for 3 additional days at $20 \pm 1^{\circ} \mathrm{C}$ to simulate the retail conditions.

\section{Sampling procedures}

Three randomly selected baskets/film $(0.375 \mathrm{~kg}$ of blueberry fruits) were sampled for each time point and the F1 was used as the control. All physicochemical analyses, with the exception of the headspace gas composition, were performed for each sample at five time points as follows: at harvest (0); after 5,10 and 15 days at a constant temperature of $1 \pm 1^{\circ} \mathrm{C}$; at $24 \mathrm{~h}$ after the change in storage temperature at 16 days $\left(20 \pm 1^{\circ} \mathrm{C}\right)$; and at the end of the storage period (18 days: 15 days at low temperature +3 days at high temperature). Sensory evaluations (consumer acceptance) were conducted after 15 and 18 days of storage.

\section{Respiration rate}

The rates of oxygen consumption $\left(\mathrm{RO}_{2}\right)$ and carbon dioxide production $\left(\mathrm{RCO}_{2}\right)$ for the blueberries were measured using a gas chromatograph (GC Varian 450, Italy) equipped with a capillary column (Molsieve 5A PLOT $30 \mu \mathrm{m} \times 30 \mathrm{~m}$ $\times 0.53 \mathrm{~mm}$ ) and a TCD detector following the permeable system [Beaudry et al., 1992]. The respiration rates in terms of $\mathrm{O}_{2}$ and $\mathrm{CO}_{2}$ at a given temperature were expressed as an average of three measurements $\left(\mathrm{mmol} \mathrm{kg}{ }^{-1} \mathrm{~h}^{-1}\right)$ according to the following equations : Eqs. (1)-(2), respectively:

$$
\mathrm{RO}_{2}=\frac{\frac{\mathrm{PO}_{2} \times \mathrm{A}}{1} \times\left(\mathrm{pO}_{2} \mathrm{~atm}-\mathrm{pO}_{2} \mathrm{pkg}\right)}{\mathrm{M}}
$$

$$
\mathrm{RCO}_{2}=\frac{\frac{\mathrm{PCO}_{2} \times \mathrm{A}}{1} \times\left(\mathrm{pCO}_{2} \mathrm{pkg}-\mathrm{pCO}_{2} \text { atm }\right)}{\mathrm{M}}
$$

where: $\mathrm{P}$ is the permeability coefficient ( $\mathrm{mmol} \mathrm{cm} \mathrm{cm} \mathrm{cm}^{-2} \mathrm{~h}^{-1} \mathrm{kPa}^{-1}$ ); A is the surface area $(\mathrm{cm}) ; 1$ is the thickness of the film $(\mathrm{cm})$; $\mathrm{p}_{\mathrm{atm}}$ is the partial atmospheric pressure $(\mathrm{kPa}) ; \mathrm{p}_{\mathrm{pkg}}$ is the pressure inside the packaging $(\mathrm{kPa})$, and $\mathrm{M}$ is the mass $(\mathrm{kg})$.

\section{Headspace gas composition}

The headspace gas composition inside each package changed during storage because of the combined effect of the cv. Duke respiration, the films acted as a barrier to gases, and the temperature. Therefore, to measure the relative changes in the carbon dioxide and oxygen concentrations, we used a $\mathrm{CO}_{2}$ and $\mathrm{O}_{2}$ analyzer (CheckPoint II, PBI Dansensor, Italy). The changes in gas composition values were measured daily over the trial period and are expressed as $\mathrm{v} / \mathrm{v} \mathrm{kPa}$. To avoid modifications in the headspace gas composition from gas sampling, the same air volume (with a free volume of $330 \mathrm{~mL}$ ) was maintained in the packages during the trial period (because of a modification to the packages made by the supplier) because the analyzer introduced the same quantity of air that it removed for the analyses. To prevent gas leakage during the measurement, an adhesive single sep- 
tum system (Septum white $15 \mathrm{~mm}$ diameter, Dansensor, Italy) was placed on the surface of the package. The results are expressed as an average of three replicates.

\section{Qualitative fruits assessment}

\section{Weight loss}

The weight (water) loss of each blueberry tray was measured by using an electronic balance (SE622, WVR, USA) with an accuracy of $0.01 \mathrm{~g}$. The weight losses are reported as a percentage of the initial fruit weight of each package (Equation 3). The results are expressed as an average of three replicates.

$$
\text { Weight loss }(\%)=\frac{\mathrm{W}_{\mathrm{O}}-\mathrm{W}_{\mathrm{t}}}{\mathrm{W}_{\mathrm{O}}}
$$

where: $\mathrm{W}_{\mathrm{o}}$ is the initial weight and $\mathrm{W}_{\mathrm{t}}$ is the weight of the sample at time $t$.

\section{Soluble solids content (SSC) and titratable acidity (TA)}

A soluble solids content (SSC) analysis was conducted by using squeezed blueberries at $20^{\circ} \mathrm{C}$. The SSC concentration was determined through the homogenization of fruits from each lot with an Atago Pal-1 pocket refractometer (Atago Co. Ltd., Japan), and it was expressed in units of ${ }^{\circ}$ Brix at $20^{\circ} \mathrm{C}$. The TA was measured by using an automatic titrator (Titritino 702, Metrohm, Swiss) and was determined potentiometrically by using $0.1 \mathrm{~N} \mathrm{NaOH}$ to an end point of pH 8.1 in $5 \mathrm{~mL}$ of juice diluted in $50 \mathrm{~mL}$ of distilled water.

\section{Total anthocyanin and phenolic contents and the antioxidant activity}

To determine the main nutraceutical compounds a preliminary extraction of blueberries was performed. To this end, $25 \mathrm{~mL}$ of the extraction solution $(500 \mathrm{~mL}$ of methanol, $23.8 \mathrm{~mL}$ of deionized water and $1.4 \mathrm{~mL}$ of $37 \%$ hydrochloric acid) were used for $10 \mathrm{~g}$ of blueberries of each sample. After $60 \mathrm{~min}$ in dark storage conditions at room temperature, a homogenized sample was obtained using the Ultra Turrax (T25, IKA WERKE, Staufen, Germany) at $3000 \mathrm{rpm}$ for $15 \mathrm{~min}$. Before the analysis the supernatant was stored at $-20^{\circ} \mathrm{C}$. The $\mathrm{pH}$ differential method of Cheng \& Breen [1991] was the base for the evaluation of the total anthocyanin content. The method was based on the difference of absorbance of anthocyanins at 510 and $700 \mathrm{~nm}$ in a buffer solution at $\mathrm{pH} 1.0$ and $\mathrm{pH} 4.5$, respectively.

Data reported as milligrams of cyanidin-3-glucoside $(\mathrm{C} 3 \mathrm{G})$ equivalents per $100 \mathrm{~g}$ of fresh weight $(\mathrm{FW})$ were calculated using the following equation:

$$
\mathrm{A}_{\text {tot }}=\left(\mathrm{A}_{515}-\mathrm{A}_{700}\right) \mathrm{pH} 1.0-\left(\mathrm{A}_{515}-\mathrm{A}_{700}\right) \mathrm{pH} 4.5 \text {. }
$$

According with the method of Slinkard \& Singleton [1977], the total pholyphenols content was evaluated with the Folin-Ciocalteu reagent with gallic acid as a standard. The absorbance was measured at $765 \mathrm{~nm}$ with a UV-Vis spectrophotometer 1600 (PC VWR International) and the data were reported as milligrams of gallic acid equivalents per $100 \mathrm{~g}$ of fresh weight $\left(\mathrm{mg}_{\mathrm{GAE}} / 100 \mathrm{FW}\right)$.
The method of Pellegrini et al. [2003], with some modifications was used to analyze the antioxidant capacity of blueberries. The capacity of the reduction of the ferric 2,4,6-tripyridyl-s-triazine (TPTZ) to its ferrous form in the TPTZ-ferric chloride solution (FRAP reagent) was measured at $595 \mathrm{~nm}$. The spectrophotometric results were expressed as mmol $\mathrm{Fe}^{2+}$ per $1 \mathrm{~kg}$ of fresh berries.

\section{Sensory evaluations}

A sensory evaluation was performed with fifteen trained panelists to assess the acceptability of blueberries packaged with the different starch corn films. Ten berries randomly selected for each sample were judged according with the main sensory descriptors (appearance, aroma, texture, flavor and overall acceptability). The 9-point hedonic scale (where $9=$ "like extremely," $8=$ "like very much", 7 = "like moderately", 6 = "like slightly" 5 = "neither like nor dislike", 4 = "dislike slightly", 3 = "dislike moderately," 2 = "dislike very much" and $1=$ "dislike extremely"), largely applied in the food and consumer research [Lim, 2011], was used to evaluate the fruits. The unacceptability of the fruits was under 3 score.

\section{Statistical analysis}

All statistics were performed using IBM-SPSS.22 for Windows [2015]. The data obtained were treated with two-way analysis of variance (ANOVA) and the means were separated using the Duncan test $(\mathrm{p} \leq 0.05)$.

\section{RESULTS AND DISCUSSION}

\section{Respiration rate of blueberries and headspace gas composition of packages}

The initial atmospheric gas composition $(0.2 \mathrm{kPa}$ $\mathrm{CO}_{2}$ and $21.2 \mathrm{kPaO}_{2}$ ) changed in the packages with all the starch films, the exchange area through the film packages $\left(550 \mathrm{~cm}^{2}\right)$ was kept constant, so the evolution of the internal atmosphere inside the baskets was passively created by the respiration rate $\left(\mathrm{RCO}_{2}\right)$ of the cv. Duke berries (Figure 1) and the permeability of the films (Table 1) to $\mathrm{O}_{2}$ and $\mathrm{CO}_{2}$ [Beaudry et al., 1992], both of which were affected by the temperature. High respiration rates generally influence negatively the quality of the products promoting the consumption of organic acids. Among berries, blueberries generally show a low respiration rate. The catabolic activity is affected more by the storage temperature than the biodegradable films used and this implies that a severe temperature control is extremely necessary to store berries along the supply chain. In fact the $\mathrm{RCO}_{2}$ values after 5 days of storage at $1 \pm 1^{\circ} \mathrm{C}$ were of $0.45,0.65$ and $0.47 \mathrm{mmol} \mathrm{kg}^{-1} \mathrm{~h}^{-1}$ respectively for the $\mathrm{F} 2$, F3 and F4 films and were similar to those reported by Harb \& Streif [2004]. These values were maintained in a similar range for all the time the fruits were maintained under low temperature. With the change of the temperature the same packaged fruits increased their metabolism achieving at the end of storage time (18 days) respectively $2.75,4.63$ and $4.27 \mathrm{mmol} \mathrm{kg}^{-1} \mathrm{~h}^{-1}$ of $\mathrm{CO}_{2}$. The gas barrier of biodegradable films changes as the temperature increases [Beaudry et al., 1992]; at $20 \pm 1^{\circ} \mathrm{C}$ the oxygen transmission rate $\left(\mathrm{O}_{2}\right)$ and the carbon dioxide transmission rate $\left(\mathrm{CO}_{2}\right)$ of all the biodegradable and compostable films (Table 1) increases more than $70 \%$ so, their barrier effects have been 


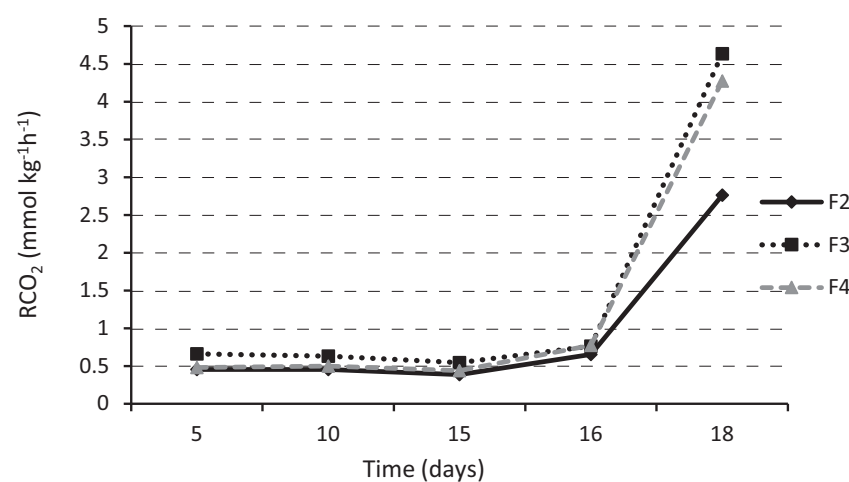

FIGURE $1 . \mathrm{CO}_{2}$ respiration rate $\left(\mathrm{RCO}_{2}\right)$ of $\mathrm{cv}$. Duke with the biodegradable and compostable films.

TABLE 1. Values of the oxygen transmission rate $\left(\mathrm{O}_{2}\right.$ TR $)$ and carbon dioxide transmission rate $\left(\mathrm{CO}_{2} \mathrm{TR}\right)$ of prototype films.

\begin{tabular}{l|c|c|c}
\hline Film & $\begin{array}{c}\text { Temperature } \\
\left({ }^{\circ} \mathrm{C}\right)\end{array}$ & $\begin{array}{c}\mathrm{O}_{2} \mathrm{TR} \\
(\mathrm{ASTMF} 2622-08) \\
\left.\mathrm{cm}^{3} / \mathrm{m}^{2} / \mathrm{d} / \mathrm{bar}\right)\end{array}$ & $\begin{array}{c}\mathrm{CO}_{2} \mathrm{TR} \\
(\mathrm{ASTMF} 2476-05) \\
\left.\mathrm{cm}^{3} / \mathrm{m}^{2} / \mathrm{d} / \mathrm{bar}\right)\end{array}$ \\
\hline \multirow{2}{*}{ F2 } & 20 & 729 & 2544 \\
& 1 & 368 & 1435 \\
F3 & 20 & 1197 & 4748 \\
& 1 & 437 & 1881 \\
F4 & 20 & 865 & 3272 \\
& 1 & 377 & 1596 \\
\hline
\end{tabular}

changed. The $\mathrm{O}_{2}$ and $\mathrm{CO}_{2}$ levels detected in the sample packages headspace during storage are reported in Figures 2 and 3, respectively. The atmosphere inside the packages with the F1 film did not change at any storage time because of the macro hole (6-mm-diameter). As expected, a decrease in the headspace $\mathrm{O}_{2}$ and an increase in the headspace $\mathrm{CO}_{2}$ over time was observed. Among all the biodegradable films, the $\mathrm{F} 3$ provides the lowest barrier effect and at $20 \pm 1^{\circ} \mathrm{C}$ the $\mathrm{CO}_{2}$ concentration achieved the lowest values. At $20 \pm 1^{\circ} \mathrm{C}$, the $\mathrm{CO}_{2}$ gas transmission rate was greater than those of $\mathrm{O}_{2}$ and at the end of the storage period (18 days), $12.6 \mathrm{kPa}, 17.2 \mathrm{kPa}$ and $22.0 \mathrm{kPa} \mathrm{CO}_{2}$ were achieved for the F3, F4 and F2 films, respectively, which corresponded to $13.3 \mathrm{kPa}, 5.8 \mathrm{kPa}$ and $2.8 \mathrm{kPa} \mathrm{O}$. The detection of off-flavors attributed to fermentation in highbush blueberries that were kept respectively to high $\mathrm{CO}_{2}$ and to low $\mathrm{O}_{2}$ concentrations are well known [Krupa \& Tomala, 2007]. Even if after 18 days the $\mathrm{O}_{2}$ gas composition inside each package strongly decreased (especially for the F4 film), all the biodegradable and compostable films well controlled the oxygen transmission rate $\left(\mathrm{O}_{2}\right.$ TR) permitting blueberries to receive enough $\mathrm{O}_{2}$ to prevent fermentation inside packages.

\section{Fruit quality assessment}

\section{Weight loss}

Maintaining the net weights of berries upon delivery is a required condition for markets. As reported in the litera-

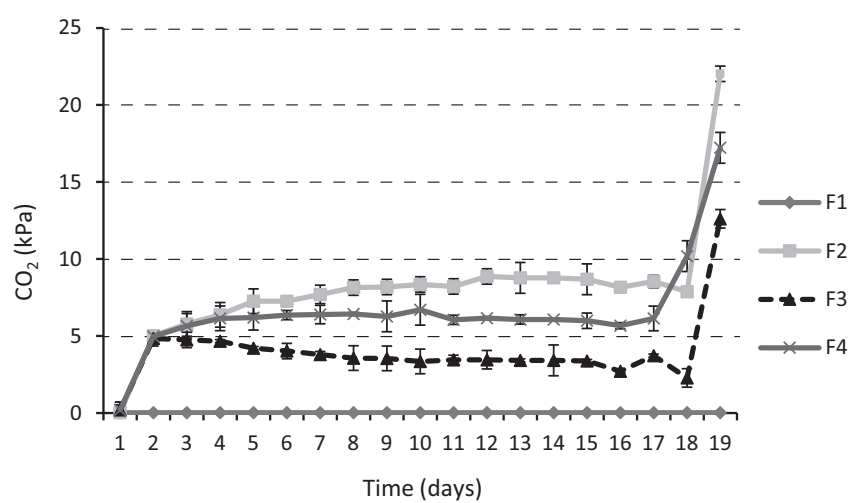

FIGURE 2. $\mathrm{CO}_{2}$ headspace concentration $(\mathrm{kPa})$ of $\mathrm{cv}$. Duke fruits during storage.

ture, weight losses of 5\% lead to wilting and poor texture, and the taste is considered critical for blueberry marketability [Almenar et al., 2008]. Considering this criterion, from our findings (Table 2) all blueberries stored with the starch films (F2, F3 and F4) would be marketable for up to 18 days. At the low temperature $\left(1 \pm 1^{\circ} \mathrm{C}\right)$, all films control weight loss well, likely because they were the only protection from mechanical damage in the case of the F1 film and they provided a protective atmosphere with the F2, F3 and F4 films. For each wrapping film, the effect of the high temperature $\left(20 \pm 1^{\circ} \mathrm{C}\right)$ was more obvious in terms of blueberry weight loss than at $1 \pm 1^{\circ} \mathrm{C}$; the highest weight losses were observed for the control $(5.30 \%)$. This trend is expected because as the temperature increases, the free energy of water molecules also increases and thus enhances the molecular movement, and the potential for exchange [Katul et al., 2012]. At the end of the storage time (18 days), the F3 film showed the lowest weight losses $(2.48 \%)$. According to the literature [Bertuzzi et al., 2007], packaging films made from renewable resources (corn starch) such as those used in this study show a naturally high permeability to water vapor; in fact, water condensation did not develop inside the MAP samples and no fungal development was observed on the fruits (data not shown).

\section{SSC and TA}

Changes in the SSC and TA levels of Duke highbush blueberries during storage are summarized in Table 3. Kader [1999] proposed a value of 10 as a minimum SSC that is acceptable for blueberry flavor. In our study, the blueberries cv. Duke at harvest showed $11.1^{\circ}$ Brix and the SSC values stayed acceptable over the whole storage period. The SSC values obtained at $1 \pm 1^{\circ} \mathrm{C}$ and $20 \pm 1{ }^{\circ} \mathrm{C}$ varied from $11.0-11.6^{\circ}$ Brix to $9.8-11.5^{\circ} \mathrm{Brix}$, respectively. According to previous studies [Rosenfeld et al., 1999], the higher SSC values were found in all packages at the lower storage temperature. Blueberries packed in MAP were reported to have a constant SSC evolution during storage at $1 \pm 1^{\circ} \mathrm{C}$ and no statistically significant differences were observed up to 15 days of storage. The difference in the SSC between the different MAP packages was noticeable with the increased temperature. All films showed SSC declines thanks to the increase in the respiration rate of the blueberries although the $\mathrm{CO}_{2}$ levels in MAP storage (F2, F3 and F4) can reduce the rate at which sugars 


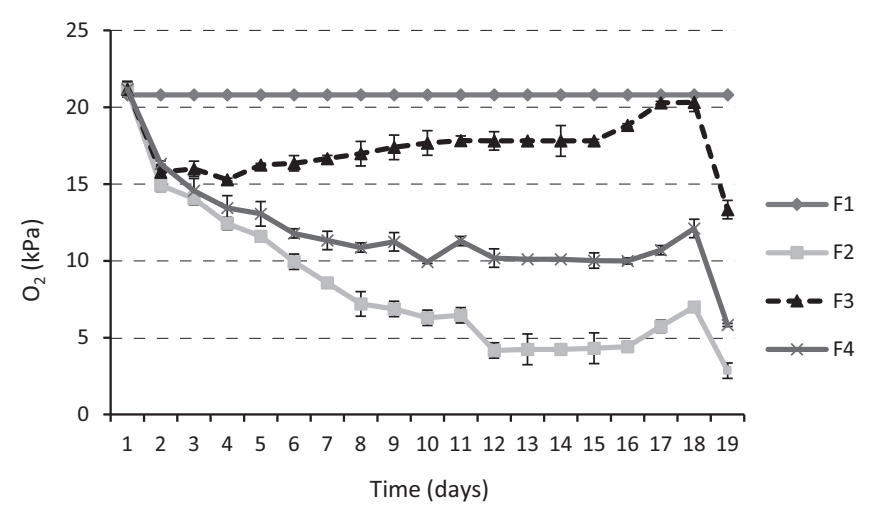

FIGURE $3 . \mathrm{O}_{2}$ headspace concentration $(\mathrm{kPa})$ of cv. Duke during storage.

are used when compared with the control treatment (F1). After 18 days of storage the F3 film showed the best performance to control the evolution of the SSC value ( $\left.10.8^{\circ} \mathrm{Brix}\right)$. The acidity of the fresh blueberries ( 0 days) was determined to be $9.24 \mathrm{meq} / \mathrm{L}$. This value was at approximately the same level in fruits packed in MAP during 15 days of storage at a low temperature $\left(1 \pm 1^{\circ} \mathrm{C}\right)$ and no differences were observed among the different starch films. The TA of fruit used as a control (F1) instead had decreased already after 10 days of cold storage as a result of blueberry ripening, which continues by converting acid to sugar. As reported in previous studies [Almenar et al., 2008], the TA values declined significantly with the change in temperature (16 days) but significantly higher TA values (7.27, 7.37 and $7.42 \mathrm{meq} / \mathrm{L})$ were observed at the end of storage (18 days) with higher $\mathrm{CO}_{2}(\mathrm{~F} 2$, F4 and F3, respectively).

Total anthocyanin and phenolic contents and antioxidant activity

The changes in nutraceutical compounds are shown in Table 4. Although the anthocyanin, phenolic contents and antioxidant activity of blueberry fruits have been previously reported, this is the first report on changes in cv. Duke after storage when using films for MAP made from starch corn. Blueberries are one of the richest sources of anthocyanins [Wu et al., 2006] and the absence of oxygen, a low pH and low processing/storage temperatures are external factors that favor the stability of anthocyanin pigments [Kalt et al., 1999]. According to previous studies [Prior et al., 2003], cv. Duke was confirmed as a valuable source of potentially healthy compounds; in fact, the total anthocyanin content at harvest was of $223.86 \mathrm{mg} \mathrm{C}_{3} \mathrm{G} / 100 \mathrm{~g} \mathrm{FW}$. Although many studies have been performed, the effects of the storage time and temperature on the behavior of the anthocyanin contents are not well known [Kalt et al., 1999; Routray \& Orsat, 2011] and the $\mathrm{CO}_{2}$-enriched atmospheric effects on their stability are also uncertain [Wang, 2007]. Our data show that for all films used, the degradation rate of anthocyanins increases as the temperature rises according to previous studies [Routray

TABLE 2. Effect of different packaging on weight loss of blueberry cv. Duke during the storage.

\begin{tabular}{|c|c|c|c|c|c|}
\hline Films & Day $5^{*}$ & Day 10 & Day $15^{*}$ & Day 16 & Day 18 \\
\hline $\mathrm{F} 1$ & $1.07 \% \pm 0.23$ & $1.81 \% \pm 0.22$ & $2.52 \% \pm 0.27$ & $2.83 \% \pm 0.30$ & $5.30 \% \pm 0.59$ \\
\hline $\mathrm{F} 2$ & $1.05 \% \pm 0.14$ & $1.65 \% \pm 0.19$ & $2.30 \% \pm 0.24$ & $2.51 \% \pm 0.20$ & $4.20 \% \pm 0.69$ \\
\hline F3 & $0.46 \% \pm 0.12$ & $0.84 \% \pm 0.10$ & $1.21 \% \pm 0.10$ & $1.39 \% \pm 0.11$ & $2.38 \% \pm 0.27$ \\
\hline $\mathrm{F} 4$ & $0.84 \% \pm 0.20$ & $1.46 \% \pm 0.27$ & $2.01 \% \pm 0.35$ & $2.15 \% \pm 0.29$ & $3.79 \% \pm 0.39$ \\
\hline
\end{tabular}

The data were expressed on means $(\%) \pm$ standard error. ${ }^{*} 5,10,15$ days at $1 \pm 1^{\circ} \mathrm{C}$ and 16,18 days at $20 \pm 1^{\circ} \mathrm{C}$.

TABLE 3. Evolution of soluble solid content (SSC) and titratable acidity of blueberry cv. Duke during the post-harvest.

\begin{tabular}{|c|c|c|c|c|c|c|}
\hline Quality parameters & Films & Day $5^{*}$ & Day 10 & Day 15 & Day 16 & Day 18 \\
\hline \multicolumn{7}{|c|}{ Harvest $11.1 \pm 0.1$} \\
\hline \multirow{4}{*}{$\mathrm{SSC}\left({ }^{\circ}\right.$ Brix $)$} & $\mathrm{F} 1$ & $11.4 \pm 0.10^{\mathrm{b} A^{* *}}$ & $11.3 \pm 0.10^{\mathrm{nsA}}$ & $11.0 \pm 0.15^{\text {ьв }}$ & $10.9 \pm 0.10^{\mathrm{bB}}$ & $9.80 \pm 0.06^{\mathrm{cC}}$ \\
\hline & F2 & $11.5 \pm 0.10^{\mathrm{abA}}$ & $11.4 \pm 0.10^{\mathrm{n} \mathrm{sAB}}$ & $11.3 \pm 0.10^{\mathrm{aB}}$ & $11.0 \pm 0.10^{\mathrm{bC}}$ & $10.5 \pm 0.06^{\mathrm{bD}}$ \\
\hline & F3 & $11.5 \pm 0.10^{\mathrm{abA}}$ & $11.4 \pm 0.10^{\mathrm{n} \mathrm{sAB}}$ & $11.2 \pm 0.12^{\mathrm{aBC}}$ & $11.1 \pm 0.10^{\mathrm{abC}}$ & $10.8 \pm 0.20^{\mathrm{aD}}$ \\
\hline & $\mathrm{F} 4$ & $11.6 \pm 0.10^{\mathrm{aA}}$ & $11.4 \pm 0.10^{\mathrm{nsA}}$ & $11.2 \pm 0.12^{\mathrm{aA}}$ & $11.5 \pm 0.10^{\mathrm{aA}}$ & $10.4 \pm 0.10^{\mathrm{bB}}$ \\
\hline \multicolumn{7}{|c|}{ Harvest $9.24 \pm 1.37$} \\
\hline \multirow{4}{*}{ TA (meq/L) } & $\mathrm{F} 1$ & $9.35 \pm 0.5^{\mathrm{nsA}}$ & $8.11 \pm 0.24^{\mathrm{bB}}$ & $7.50 \pm 0.53^{\mathrm{bBC}}$ & $6.74 \pm 0.83^{\mathrm{bCD}}$ & $6.40 \pm 0.40^{\mathrm{bD}}$ \\
\hline & F2 & $9.64 \pm 0.1^{\mathrm{nsA}}$ & $9.69 \pm 0.37^{\mathrm{aA}}$ & $9.48 \pm 0.24^{\mathrm{aA}}$ & $7.77 \pm 0.32^{\mathrm{abB}}$ & $7.27 \pm 0.08^{\mathrm{aC}}$ \\
\hline & F3 & $9.38 \pm 0.3^{\mathrm{nsA}}$ & $9.58 \pm 0.32^{\mathrm{aA}}$ & $9.48 \pm 0.29^{\mathrm{aA}}$ & $7.97 \pm 0.55^{\mathrm{aв}}$ & $7.42 \pm 0.15^{\mathrm{aB}}$ \\
\hline & $\mathrm{F} 4$ & $9.87 \pm 0.1^{\mathrm{nsA}}$ & $9.48 \pm 0.35^{\mathrm{aA}}$ & $9.51 \pm 0.38^{\mathrm{aA}}$ & $7.29 \pm 0.17^{\mathrm{abB}}$ & $7.37 \pm 0.30^{\mathrm{aB}}$ \\
\hline
\end{tabular}

* 5,10, 15 days at $1 \pm 1{ }^{\circ} \mathrm{C}$ and 16,18 days at $20 \pm 1^{\circ} \mathrm{C}$. "Values in the column followed by different lowercase letters and lines followed by different uppercase letters are significantly $(\mathrm{p}<0.05)$ different according to Duncan's test. 
TABLE 4. Evolution of nutraceutical compounds of blueberry cv. Duke during the post-harvest.

\begin{tabular}{|c|c|c|c|c|c|c|}
\hline $\begin{array}{l}\text { Nutraceutical } \\
\text { compounds }\end{array}$ & Films & Day $5^{*}$ & Day 10 & Day 15 & Day 16 & Day 18 \\
\hline \multirow{5}{*}{$\begin{array}{l}\text { Total } \\
\text { anthocyanins } \\
\left(\mathrm{mg}_{\mathrm{C} 3 \mathrm{G}} / 100 \mathrm{FW}\right)\end{array}$} & \multicolumn{6}{|c|}{ Harvest $223.86 \pm 18.28$} \\
\hline & $\mathrm{F} 1$ & $266.71 \pm 32.71^{\mathrm{ns}^{* * *} A^{* * * *}}$ & $269.83 \pm 22.91^{\mathrm{aA}}$ & $161.58 \pm 17.10^{\mathrm{nsB}}$ & $146.26 \pm 14.69^{\mathrm{nsB}}$ & $155.44 \pm 26.56^{\mathrm{nsB}}$ \\
\hline & $\mathrm{F} 2$ & $210.19 \pm 22.70^{\mathrm{nsA}}$ & $181.06 \pm 23.17^{\mathrm{bcAB}}$ & $141.71 \pm 17.59^{\mathrm{nsBC}}$ & $160.47 \pm 26.16^{\mathrm{nsABC}}$ & $119.97 \pm 37.25^{\mathrm{nsC}}$ \\
\hline & F3 & $255.41 \pm 86.44^{\mathrm{nsA}}$ & $204.63 \pm 29.52^{\mathrm{bAB}}$ & $181.00 \pm 28.16^{\mathrm{nAAB}}$ & $123.59 \pm 37.48^{\mathrm{nsB}}$ & $156.21 \pm 11.82^{\mathrm{nsB}}$ \\
\hline & $\mathrm{F} 4$ & $213.03 \pm 39.64^{\mathrm{nsA}}$ & $142.11 \pm 32.89^{\text {ьв }}$ & $150.80 \pm 28.65^{\mathrm{nsB}}$ & $120.49 \pm 28.01^{\mathrm{nsB}}$ & $114.52 \pm 27.60^{\mathrm{nsB}}$ \\
\hline \multirow{5}{*}{$\begin{array}{l}\text { Total polyphenols } \\
\left(\mathrm{mg}_{\mathrm{GAE}} / 100 \mathrm{FW}\right)\end{array}$} & \multicolumn{6}{|c|}{ Harvest $491.54 \pm 19.01$} \\
\hline & $\mathrm{F} 1$ & $506.90 \pm 15.01^{\mathrm{nAAB}}$ & $535.11 \pm 69.40^{\mathrm{aA}}$ & $434.79 \pm 47.96^{\mathrm{nBBC}}$ & $374.24 \pm 21.02^{\mathrm{nsCD}}$ & $332.65 \pm 30.30^{\mathrm{bD}}$ \\
\hline & $\mathrm{F} 2$ & $450.72 \pm 27.89^{\mathrm{nsA}}$ & $425.01 \pm 31.22^{\mathrm{bAB}}$ & $419.99 \pm 10.61^{\mathrm{nsAB}}$ & $365.07 \pm 55.74^{\mathrm{nsB}}$ & $422.80 \pm 59.62^{\mathrm{aAB}}$ \\
\hline & F3 & $492.22 \pm 56.66^{\mathrm{nsA}}$ & $483.16 \pm 18.46^{\mathrm{abA}}$ & $387.23 \pm 25.06^{\mathrm{nsB}}$ & $378.53 \pm 37.54^{\mathrm{nsB}}$ & $368.19 \pm 52.92^{\mathrm{aB}}$ \\
\hline & $\mathrm{F} 4$ & $495.56 \pm 44.46^{\mathrm{nsA}}$ & $387.30 \pm 97.01^{\mathrm{bB}}$ & $378.50 \pm 32.69^{\mathrm{nsB}}$ & $365.40 \pm 24.96^{\mathrm{nsB}}$ & $366.60 \pm 20.27^{\mathrm{aB}}$ \\
\hline \multirow{5}{*}{$\begin{array}{l}\text { Total Antioxidant } \\
\text { Capacity (mmol } \\
\left.\mathrm{Fe}^{2+} / \mathrm{kg}\right)\end{array}$} & \multicolumn{6}{|c|}{ Harvest $23.25 \pm 0.72$} \\
\hline & $\mathrm{F} 1$ & $22.37 \pm 0.27^{\mathrm{nsNS}}$ & $21.36 \pm 1.60^{\mathrm{bNS}}$ & $22.89 \pm 0.54^{\mathrm{ans}}$ & $22.81 \pm 1.63^{\mathrm{ans}}$ & $21.16 \pm 1.12^{\mathrm{bNS}}$ \\
\hline & $\mathrm{F} 2$ & $22.80 \pm 0.50^{\mathrm{nsA}}$ & $22.92 \pm 0.20^{\mathrm{aA}}$ & $22.72 \pm 0.70^{\mathrm{aA}}$ & $20.98 \pm 0.97^{\mathrm{bB}}$ & $22.16 \pm 1.39^{\mathrm{aAB}}$ \\
\hline & F3 & $23.65 \pm 1.50^{\mathrm{nsNS}}$ & $22.22 \pm 1.00^{\mathrm{aNS}}$ & $22.52 \pm 0.40^{\mathrm{aNS}}$ & $22.20 \pm 0.60^{\mathrm{aNS}}$ & $22.18 \pm 0.29^{\mathrm{aNS}}$ \\
\hline & $\mathrm{F} 4$ & $23.60 \pm 0.82^{\mathrm{nsA}}$ & $22.95 \pm 0.38^{\mathrm{aAB}}$ & $21.79 \pm 0.37^{\mathrm{bBC}}$ & $21.75 \pm 0.47^{\mathrm{aBC}}$ & $21.51 \pm 1.22^{\mathrm{aC}}$ \\
\hline
\end{tabular}

$* 5,10,15$ days at $1 \pm 1{ }^{\circ} \mathrm{C}$ and 16,18 days at $20 \pm 1^{\circ} \mathrm{C}$. ${ }^{* *}$ ns $=$ not significant. ${ }^{* * *}$ Values in the column followed by different lowercase letters and lines followed by different uppercase letters are significantly $(\mathrm{p}<0.05)$ different according to Duncan's test.

\& Orsat, 2011]. All samples showed a decrease in the total anthocyanin content if compared with the values at harvest, as a consequence of decreases in the TA values and increases in weight loss during storage. After 15 days of storage at $1 \pm 1{ }^{\circ} \mathrm{C}$, anthocyanin decreases of $27.8 \%, 36.7 \%, 18.8 \%$ and $32.7 \%$ were observed for the F1, F2, F3 and F4 films, respectively, and at the end of the storage time (18 days), the fruits wrapped with the same films lost $30.5 \%, 46.3 \%$, $30.5 \%$ and $48.9 \%$ of their initial anthocyanin values. Among all the starch films, the F3 maintained the highest anthocyanin content (181.00 and $156.21 \mathrm{mg} \mathrm{C}_{3} \mathrm{G} / 100 \mathrm{~g} \mathrm{FW}$, respectively) after 15 and 18 days with the highest $\mathrm{O}_{2} \mathrm{kPa}$ measured inside the packages [Kalt et al., 1999] during the entire storage time.

The total phenolic content of the cv. Duke at harvest was $491.54 \mathrm{mg} \mathrm{GAE} / 100 \mathrm{~g} \mathrm{FW}$, and it was within the range of values found in previous studies [Howard \& Hager, 2007]. For all the packages, the change in the total phenolic content occurred more slowly at the lower temperature $\left(1 \pm 1^{\circ} \mathrm{C}\right)$. Even when the berries were subjected to metabolic stress from the change in temperature $\left(20 \pm 1^{\circ} \mathrm{C}\right)$, the $\mathrm{F} 2$, F3 and F4 films can help to maintain high nutritional values in fruits and no significant differences were found among the starch films (422.80, 368.19 and $366.60 \mathrm{mg}$ GAE /100 g $\mathrm{FW}$, respectively).

The total antioxidant capacity in blueberries cv. Duke was $23.25 \mathrm{Fe}^{2+} / \mathrm{kg}$, which is correlated especially well with the anthocyanin and phenolic compound contents. These fruits may be considered as one of the highest antioxidant sources among fruits and vegetables [Vrhovsek et al., 2012]. During the whole storage time, the antioxidant capacity of the blueberry fruits decreased in comparison with fresh fruits according to previous studies [Remberg et al., 2003] although they still maintained their value near harvest time. Among all the starch films, the F3 was the only one able to maintain a stable antioxidant capacity for the whole storage time ranging to $23.65 \mathrm{Fe}^{2+} / \mathrm{kg}$ (5 days) to $22.18 \mathrm{Fe}^{2+} / \mathrm{kg}$ (18 days).

\section{Sensory evaluations}

In general, sensory analysis is a good tool to evaluate the impact on consumer acceptability. Sensory evaluation was performed to see if $\mathrm{CO}_{2}$ managed using the different films affected the blueberries quality. It is seen from Figure 4 that the effect of the temperature is more important than that of films used. All the mean scores of sensory attributes for the control (F1) and MAP samples (F2, F3 and F4) recorded a decrease in the shelf life storage (18 days) due the increase of the temperature. Differences in weight loss (Table 2) explained why the F3 film recorded the best consumer evaluations in term of appearance and texture while the highest balance between sugar and acid content influenced largely the flavor attribute. Generally blueberries wrapped with the F3 film showed the highest score both after 15 days $\left(1 \pm 1^{\circ} \mathrm{C}\right)$ than after 18 days $\left(20 \pm 1^{\circ} \mathrm{C}\right)$ of storage while the $\mathrm{F} 1$ film effects on the consumer acceptability were negative in terms of all descriptors used.

\section{CONCLUSION}

The data obtained in this study demonstrated the possible use of starch films for MAP in the post-harvest storage of blueberries. The use of these materials can increase 

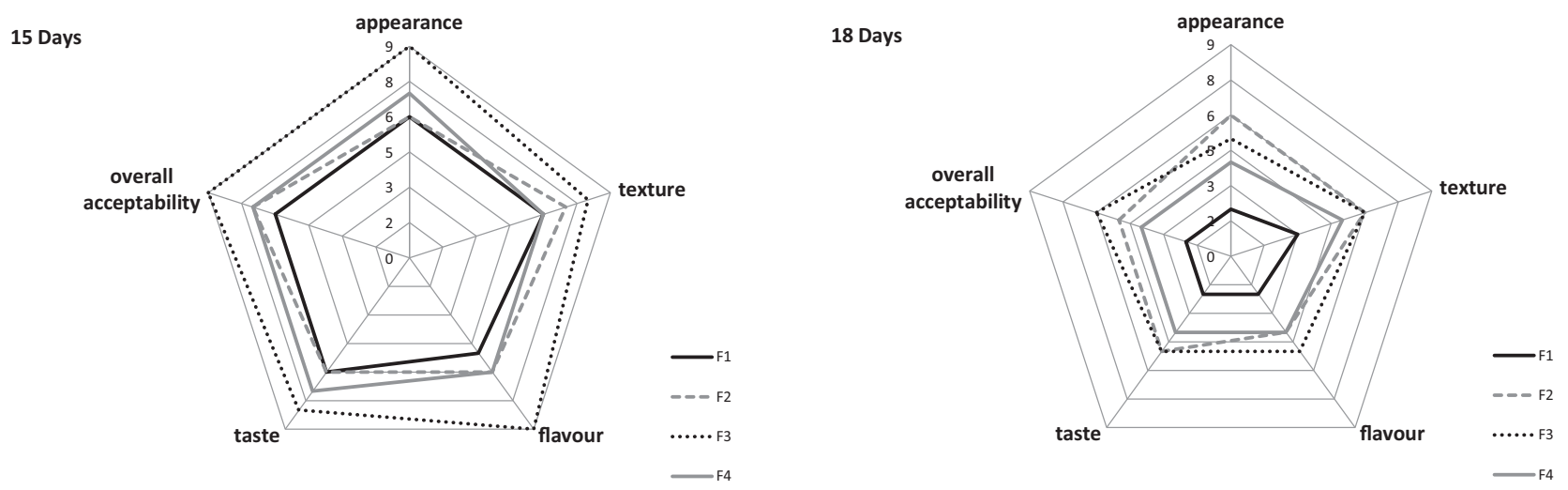

FIGURE 4. Radar chart for sensory evaluation of cv. Duke after 15 and 18 days of storage at $1 \pm 1^{\circ} \mathrm{C}$ and $20 \pm 1{ }^{\circ} \mathrm{C}$.

the environmental sustainability of the food packaging sector. The knowledge of the behavior of the gas diffusivity of these new wrapping films at different temperature is very important to provide the evolution of gas inside the packages of fruits during the supply chain and the marketing especially when the storage temperature shifts and is outside of the cold range requested by berries. The MAP storage with the starch films helped to control changes in post-harvest physicochemical properties, such as the $\mathrm{pH}$ and TA. Generally, the F2, F3 and F4 films were also capable of maintaining the antioxidant and nutritional values of fruits after 15 days of storage when the berries were subject to metabolic stress from changes in temperature. The F3 film was more likely to maintain the most important qualitative and nutraceutical traits close to those at harvest because it showed more equilibrated film selectivity throughout the storage time. To improve and to validate the use of these films in the post-harvest supply chain of fruits, it could be interesting to test these materials on other fresh products with different physiology.

\section{ACKNOWLEDGEMENTS}

The authors gratefully acknowledge Dr. Sebastià Gestì, Novamont Spa for the technical support.

\section{RESEARCH FUNDING}

This work was conducted with the financial support of the Ministry of Economic Development-Industrial 2015, New Technologies for "Made in Italy"-Vivo pack.

\section{CONFLICT OF INTEREST}

Authors declare no conflict of interest.

\section{REFERENCES}

1. Almenar E., Samsudin H., Auras R., Harte B., Rubino M., Postharvest shelf life extension of blueberries using a biodegradable package. Food Chem., 2008, 110, 120-127.

2. Almenar E., Samsudin H., Auras R., Harte B., Consumer acceptance of fresh blueberries in bio-based packages. J. Sci. Food Agric., 2010, 90, 1121-1128.
3. Alsmairat N., Contreras C., Hancock J., Callow P., Beaudry R., Use of combinations of commercially relevant $\mathrm{O}_{2}$ and $\mathrm{CO}_{2}$ partial pressures to evaluate the sensitivity of nine highbush blueberry fruit cultivars to controlled atmospheres. HortScience, 2011, 46, 74-79.

4. Beaudry R.M., Cameron A.C., Shirazi A., Dostallange D.L., Modified atmosphere packaging of blueberry fruit - Effect of temperature on package $\mathrm{O}_{2}$ and $\mathrm{CO}_{2}$. J. Am. Soc. Hortic. Sci., 1992, 117, 436-441.

5. Bertuzzi M.A., Castro Vidaurre E.F., Armada M., Gottifredi J.C., Water vapor permeability of edible starch based films. J. Food Eng., 2007, 80, 972-978.

6. Bower C., Postharvest handling, storage, and treatment of fresh market berries. 2007, in: Berry Fruits Value Added Products for Health Promotion (ed. Y. Zhao). Taylor \& Francis Group, New York, pp. 262-284.

7. Briano R., Giuggioli N., Girgenti V., Peano C., Biodegradable and compostable film and modified atmosphere packaging in postharvest supply chain of raspberry fruits (cv. Grandeur ${ }^{\circledR}$ ). J. Food Process. Pres., 2015, 39, 2061-2073.

8. Briassoulis D., Mistriotis A., Giannoulis A., Giannopoulos D., Optimized PLA-based EMAP systems for horticultural produce designed to regulate the targeted in-package atmosphere. Ind. Crops Prod., 2013, 48, 68-80.

9. Cheng G.W., Breen P.J., Activity of phenylalanine ammonialyase (PAL) and concentrations of anthocyanins and phenolics in developing strawberry fruit. J. Am. Soc. Hortisci., 1991, 116, 865-869.

10. Díaz P., Henríquez O., Enrione J., Matiacevich S., Thermal transitions of pulp and cuticle of blueberries. Thermochim. Acta, 2011, 525, 56-61.

11. Duarte C., Guerra M., Daniel P., Camelo A.L., Yommi A., Quality changes of highbush blueberries fruit stored in CA with different $\mathrm{CO}_{2}$ levels. J. Food Sci., 2009, 74, S154-S159.

12. Faostat. Food and Agriculture Organisation of the United nations: Agricultural Statistical Database, 2012.

13. Girgenti V., Peano C., Bounous M., Baudino C., A life cycle assessment of non-renewable energy use and greenhouse gas emissions associated with blueberry and raspberry production in northern Italy. Sci. Total Environ., 2013, 458-460, 414-418.

14. Harb J.Y., Streif J., Controlled atmosphere storage of highbush blueberries cv. "Duke". Eur. J. Hortic. Sci., 2004, 69, 66-72.

15. Howard L.R., Hager TJ., Berry fruit phytochemicals 2007, in: Berry Fruits Value Added Products for Health Promotion (ed. Y. Zhao). Taylor \& Francis Group, New York, pp. 73-104. 
16. Joo M.J., Lewandowski N., Auras R., Harte J., Almenar E., Comparative shelf life study of blackberry fruit in bio-based and petroleum-based containers under retail storage conditions. Food Chem., 2011, 126, 1734-1740.

17. Junqueira-Gonçalves M.P., Alarcón E., Niranjan K., Development of antifungal packaging for berries extruded from recycled PET. Food Contr., 2013, 33, 455-460.

18. Kader A.A., Fruit maturity, ripening, and quality relationships. Acta Hort., 1999, 485, 203-208.

19. Kalt W., Forney C.F., Martin A., Prior R.L., Antioxidant capacity, vitamin $\mathrm{C}$, phenolics, and anthocyanins after fresh storage of small fruits. J. Agric. Food Chem., 1999, 47, 4638-4644.

20. Katul G.B., Oren R., Manzoni S., Higgins C., Parlange M.B., Evapotranspiration: a process driving mass transport and energy exchange in the soil-plant-atmosphere-climate system. Rev. Geophys. 2012, 50, RG3002.

21. Krupa T., Tomala K., Antioxidant capacity, anthocyanin content profile in 'Bluecrop' blueberry fruit. Veg. Crops Res. Bull., 2007, 66, 129-141.

22. Lim J., Hedonic scaling: a review of methods and theory. Food Qual. Prefer., 2011, 22,733-747.

23. Paniagua A.C., East A.R., Heyes J.A., Interaction of temperature control deficiencies and atmosphere conditions during blueberry storage on quality outcomes. Postharv. Biol. Technol., 2014, 95, $50-59$.

24. Peano C., Girgenti V., Palma A., Fontanella E., Giuggioli N., Film type and MAP on cv. Himbo Top raspberry fruit quality, composition and volatiles. Ital. J. Food Sci., 2013, 25, 1421-1432.

25. Peelman N., Ragaert P., De Meulenaer B., Adons D., Peeters R., Cardon L., Van Impe F., Devlieghere F., Application of bioplastics for food packaging. Trends Food Sci. Technol., 2013, 32, 128-141.

26. Pellegrini N., Serafini M., Colombi B., Del Rio D., Salvatora S., Bianchi M., Total antioxidant capacity of plant foods, beverages and oils consumed in Italy by three different in vitro assays. J. Nutr., 2003, 133, 2812-2819.

27. Perkins-Veazie P., Blueberry 2004, in: The Commercial Storage of Fruits, Vegetables, and Florist and Nursery Stocks (eds. K.C. Gross, C.Y. Wang, M. Saltveit). USDA, ARS, Beltsville.

28. Prange R.K., Asiedu S.K., DeEll J.R., Westgarth A.R., Quality of fundy and blomidon lowbush blueberries: effects of storage atmosphere, duration and fungal inoculation. Can. J. Plant Sci., 1995, 75, 479-483.

29. Prior R.L., Hoang H., Gu L., Wu X., Bacchiocca M., Assays for hydrophilic and antioxidant capacity (oxygen radical absorbance capacity (ORAC FL) of plasma and other biological and food samples. J. Agric. Food Chem., 2003, 51, 3273-3279.

30. Remberg S., Haffner K., Blomhoff R., Total antioxidant capacity and other quality criteria in blueberries cvs. 'Bluecrop, 'Hardyblue', 'Patriot', 'Putte' and 'Aron' after storage in cold store and controlled atmosphere. Acta Hort., 2003, 600, 595-598.

31. Rosenfeld H.J., Meberg K.R., Haffner K., Sundell H.A., MAP of highbush blueberries: sensory quality in relation to storage temperature, film type and initial high oxygen atmosphere. Postharv. Biol. Technol., 1999, 16, 27-36.

32. Routray W., Orsat V., Blueberries and their anthocyanins: factors affecting biosynthesis and properties. Compr. Rev. Food Sci. Food Safety, 2011, 11, 303-320.

33. Slinkard K., Singleton V.L., Total phenol analysis: Automation and comparison with manual methods. Am. J. Enol. Vitic., 1977, 28, 49-55.

34. Vrhovsek U., Masuero D., Palmieri L., Mattivi F., Identification and quantification of flavonol glycosides in cultivated blueberry cultivars. J. Food Compos. Anal., 2012, 25, 9-16.

35. Wang S.Y., Antioxidant capacity and phenolic content of berry fruits as affected by genotype, preharvest conditions, maturity, and postharvest handling. 2007, in: Berry Fruits Value Added Products for Health Promotion (ed. Y. Zhao). Taylor \& Francis Group, New York, pp. 147-178.

36. Wikström F., Williams H., Verghese K., Clune S., The influence of packaging attributes on consumer behaviour in food-packaging life cycle assessment studies - a neglected topic. J. Clean Prod., 2014, 73, 100-108.

37. Wu X., Beecher G.R., Holden J.M., Haytowitz D.B., Gebhardt S.E., Prior R.L., Concentrations of anthocyanins in common foods in the United States and estimation of normal consumption. J. Agric. Food Chem., 2006, 54, 4069-4075.

38. Yam K.L., Lee D.S., Design of modified atmosphere packaging for fresh produce. 1995, in: Active Food Packaging (ed. M.L. Rooney). Blackie Academic, London, pp. 55-73.

Submitted: 3 December 2015. Revised: 21 April and 29 April 2016. Accepted: 9 May 2016. Published on-line: 5 September 2016. 